\author{
Mikotaj Bartlomiejczyk \\ Przedsiębiorstwo Komunikacji Trolejbusowej \\ Sp. z o.o. w Gdyni \\ Politechnika Gdańska \\ Katedra Inżynierii Elektrycznej Transportu \\ Wydziat Elektrotechniki i Automatyki \\ Marcin Polom \\ Przedsiębiorstwo Komunikacji Trolejbusowej \\ Sp. z o.o. w Gdyni \\ Uniwersytet Gdański \\ Instytut Geografii \\ Wydziat Oceanografii i Geografii
}

\title{
Możliwości ograniczenia zużycia energii w transporcie miejskim na przykładzie gdyńskiej komunikacji trolejbusowej
}

\begin{abstract}
W artykule przedstawiono analize możliwości zwiększenia efektywności hamowania odzyskowego na przykładzie gdyńskiej sieci trolejbusowej. Przedmiotem sq dwa sposoby osiagnięcia tego celu: instalacja zasobników superkondensatorowych na podstacjach trakcyjnych oraz wprowadzenie do eksploatacji dwustronnego zasilania sieci trakcyjnej. Pierwszy zasobnik superkondensatorowy zostat zainstalowany $w$ Gdyni w kwietni 2011 roku natomiast wprowadzenie dwustronnego zasilania jest planowane $w$ przyszłości.
\end{abstract}

\section{Wstęp}

Przedsiębiorstwo Komunikacji Trolejbusowej Sp. z o.o. w Gdyni prowadzi obecnie wymianę parku taborowego na szeroko zakrojoną skalę. Na miejsce dotychczasowych trolejbusów, wyposażonych w stycznikowo - rezystorową regulację prędkości, wprowadzane do eksploatacji są nowoczesne pojazdy $\mathrm{z}$ energoelektroniczną regulacją prędkości, wyposażone w możliwość hamowania odzyskowego do sieci trakcyjnej. $Z$ jednej strony powoduje to spadek zużycia energii będący rezultatem wzrostu sprawności układów napędowych, z drugiej zaś strony widoczny jest wzrost ilości energii zwracanej do sieci, skutkiem czego spada efektywność wykorzystania hamowania odzyskowego. Uzasadnione staje się więc podjęcie kroków mających na celu zwiększenie efektywności wykorzystania energii rekuperacji.

\section{Zastosowanie podstacyjnych superkondensato- rowych zasobników}

W 2009 roku Przedsiębiorstwo Komunikacji Trolejbusowej Sp. z o.o. (PKT) w Gdyni nawiązało współpracę z Zakładem Trakcji Instytutu Elektrotechniki w Warszawie (IEL) celem wprowadzenia do testowej eksploatacji w Gdyni zasobnika superkondensatorowego umieszczonego na jednej $\mathrm{z}$ gdyńskich podstacji trakcyjnych. IEL zdecydował się na wykonanie dwóch bliźniaczych zasobników:
- jednego dla Tramwajów Elbląskich, z przeznaczeniem instalacji na pętli tramwajowej. Zadaniem tego zasobnika miała być redukcja spadków napięcia w sieci trakcyjnej,

- drugiego dla PKT Gdynia, z przeznaczeniem instalacji na podstacji trakcyjnej. W odróżnieniu od wykonania elbląskiego, gdyński zasobnik miał na celu ograniczenie zużycia energii poprzez akumulację niewykorzystanej energii hamowania odzyskowego.

Celem minimalizacji kosztów IEL zdecydował się na unifikację obydwu rozwiązań Pierwszy z zasobników - wykonany dla Tramwajów Elbląskich - został zainstalowany w październiku 2010 roku. Gdyński zasobnik zamontowano w kwietniu 2011.

Jako miejsce lokalizacji gdyńskiego zasobnika wybrano trolejbusową podstację trakcyjną Pótnocna. Jest to dwuzespołowa podstacja trakcyjna, która była poddana całkowitej modernizacji w sierpniu 2010 roku. Wyposażona jest ona $\mathrm{w}$ dwa zespoły prostownikowe o mocy transformatorów 1200 kVA każdy i zasila 6 zasilaczy. Obecnie jest to największa podstacja trakcyjna w gdyńskiej sieci trolejbusowej. Zasobnik ten został umieszczony w miejscu przeznaczonym na ewentualną instalację trzeciego zespołu prostownikowego (rys. $1 \mathrm{a}, \mathrm{b}$ ). 
a)



b)

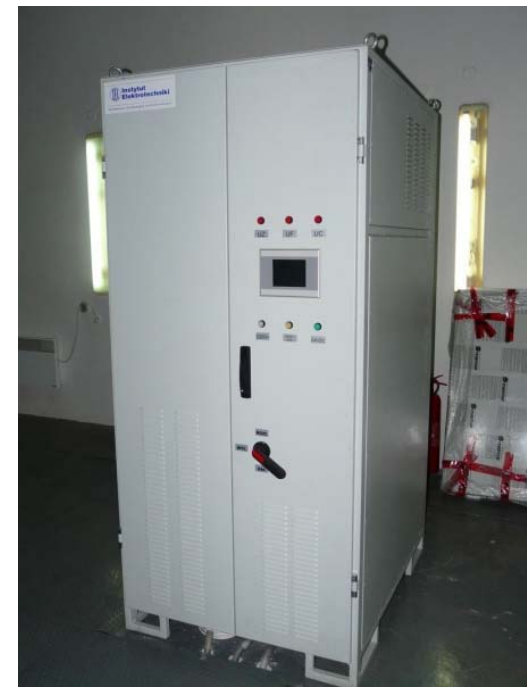

Rys. 1. Zasobnik superkondensatorowy zainstalowany w trolejbusowej podstacji trakcyjnej Pólnocna w Gdyni.

Zasobnik składa się z następujących zasadniczych elementów (rys. 2):

- modułu wejściowego, zawierającego zabezpieczenia oraz filtr wejściowy (F1, XO, CF1),

- przekształtnika DC / DC podwyższająco - obniżającego napięcie (T0, T1, T2, D0, CF2, X1) o mocy $150 \mathrm{~kW}$,

- czterech modułów superkondensatorowych LS MTron 201,6 V 41 F (SC1),

- rezystora rozładowczego superkondensatorów R2,

- układu sterowania.



Rys. 2. Uproszczony schemat ideowy zasobnika

Pojemność energetyczna obecnie zainstalowanych modułów superkondensatorowych wynosi 0,7 kWh. Modułowa konstrukcja zasobnika umożliwia jednak jego rozbudowę o drugi pakiet superkondensatorów (oznaczono to linią przerywaną na rys. 2) do całkowitej pojemności $1,5 \mathrm{kWh}$. W przypadku konieczności jeszcze większego zwiększenia pojemności, możliwa jest równoległa praca kilku układów zasobnikowych. Na rys. 3 a, b przedstawiono fotografie wnętrza zasobnika, linią przerywaną oznaczono elementy przewidziane do wykonania $\mathrm{w}$ przypadku instalacji drugiego pakietu modułów superkondensatorowych.

\section{Dwustronne zasilanie sieci trakcyjnej}

Alternatywnym sposobem zwiększenia efektywności hamowania odzyskowego w komunikacji miejskiej jest wprowadzenie dwustronnego zasilania sieci trakcyjnej. Przykładowa analiza takiego rozwiązania zostanie przeprowadzona dla planowanego połączenia dwóch gdyńskich trolejbusowych podstacji trakcyjnych: a)

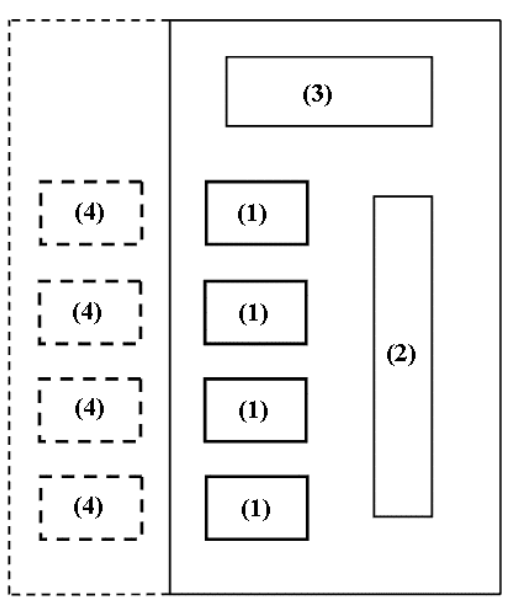

b)

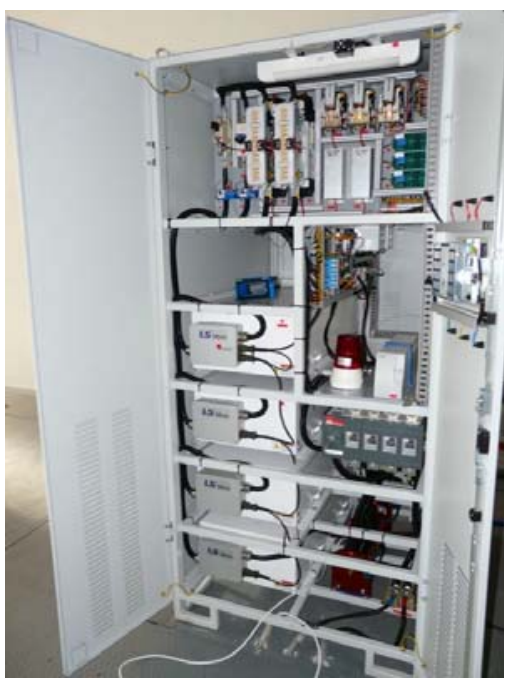

Rys. 3. Zasobnik superkondensatorowy zainstalowany w trolejbusowej podstacji trakcyjnej Pótnocna w Gdyni; a - schemat rozmieszczenia aparatury, $\mathrm{b}$ - widok aparatury $(1-$ moduły superkondensatorowe, 2 - przekształtnik DC/DC wraz z układem sterowania, 3 - moduł zabezpieczeń i filtru wejściowego, 4 - moduły superkondensatorowe przewidziane do instalacji w przyszłości). 
- podstacji Wielkopolska, wyposażonej w jeden zespół prostownikowy o mocy $800 \mathrm{kVA} \mathrm{i}$ zasilającej jeden zasilacz,

- podstacji Chwaszczyńska, wyposażonej we dwa zespoły prostownikowe o mocy 1200 kVA każdy i zasilającej 5 zasilaczy.

Obydwie podstacje znajdują się $\mathrm{w}$ górzystej części Gdyni (rys. 4).

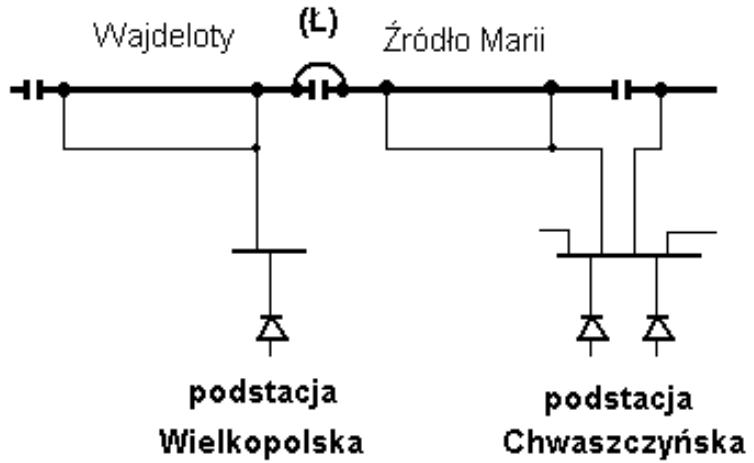

Rys. 4. Schemat proponowanego układu dwustronnego zasilania,

(Ł) - połączenie pomiędzy odcinkami zasilania Źródło Marii i Wajdeloty

Rozważone zostaną dwa sposoby osiagnięcia tego celu, a mianowicie:

1) instalacja superkondensatorowych zasobników energii na obydwu podstacjach, celem gromadzenia energii powstającej podczas rekuperacji,

2) wprowadzenie do eksploatacji dwustronnego zasilania odcinków Wajdeloty i Źródto Marii poprzez ich połączenie, co umożliwi przepływ energii rekuperacji (rys. 2).

W oparciu o opracowaną metodę Monte Carlo modelowania układu zasilania komunikacji trolejbusowej, przeprowadzono porównanie wariantów zwiększenia stopnia wykorzystania rekuperacji w obszarze zasilania podstacji Chwaszczyńska i Wielkopolska. Symulacje przeprowadzono na bazie obecnych rozkładów jazdy trolejbusów, a więc założono, że na analizowanym obszarze czynne jest pięć linii o numerach: 23, 24, 27, 29 i 31. Do obliczeń przyjęto również założenie, iż wszystkie linie trolejbusowe beda obsługiwane trolejbusami Solaris Trollino 12, wyposażonymi $\mathrm{W}$ układ napędowy $\mathrm{z}$ silnikiem asynchronicznym o mocy $175 \mathrm{~kW}$ i posiadającymi możliwość techniczną hamowania odzyskowego do sieci trakcyjnej. Profil prędkości oparto o aktualne rozkłady jazdy oraz drogowe ograniczenia prędkości.

$\mathrm{Z}$ obliczeń wynika, że $\mathrm{w}$ przypadku wariantu podstawowego układu zasilania, czyli zasilania przedmiotowego obszaru z dwóch odseparowanych galwanicznie podstacji, całkowite roczne zużycie energii elektrycznej wyniesie około $2,4 \mathrm{GWh}$, co odpowiada kosztom energii elektrycznej około 450 tys. zł. Wprowadzenie dwustronnego zasilania przyniesie roczną oszczędność około 32 tys. zł. Natomiast instalacja zasobników spowoduje zmniejszenie zużycia energii elektrycznej na kwotę 117 tys. zł. Przy założeniu dziesięcioletniej żywotności zasobników, można stwierdzić, iż inwestycja ta będzie uzasadniona ekonomicznie przy maksymalnej cenie zasobnika około 585 tys. zł. Oszczędności wynikające z wprowadzenia dwustronnego zasilania sieci trakcyjnej są znacznie mniejsze od oszczędności uzyskanych w wyniku instalacji zasobników superkondensatorowych, jednak nakłady finansowe związane $\mathrm{z}$ uruchomieniem dwustronnego zasilania sieci trakcyjnej (wariant nr 3) są także znacznie mniejsze.

\section{Podsumowanie}

Przedstawione powyżej rozwiązania wskazują na szeroki wachlarz możliwości ograniczenia zużycia energii trakcyjnej poprzez zwiększenie efektywności wykorzystania hamowania odzyskowego. Będzie to $\mathrm{z}$ pewnościa priorytet $\mathrm{w}$ działaniach PKT Gdynia w najbliższej przyszłości.

\section{Literatura}

[1] SZELAG A.: Analiza obciqżeń uktadu zaislania trakcji elektrycznej systemu prqdustatego metoda symulacji komputerowej, rozprawa doktorska. Warszawa 1989, Politechnika Warszawska

[2] SZELAG A.: Zagadnienia analizy $i$ projektowania systemu trakcji elektrycznej pradu stałego zastosowaniem technik modelowania $i$ symulacji. Warszawa 2002, Politechnika Warszwska

[3] DRĄŻEK Z.: Symulacyjna metoda analizy systemów zasilania elektrycznej trakcji miejskiej pradu stałego, rozprawa doktorska. Warszawa 1998, Politechnika Warszawska

[4] GOEASZEWSKI T.: Obliczenia obciażeń uktadu zasilania sieci tramwajowej przy wykorzystaniu metody Monte Carlo, praca dyplomowa. Warszawa 2000, Politechnika Warszawska

[5] Probabilistic load flow in AC electrified railways. T.K. Ho, IEE Proc-Electr. Power Appl, vol 152, No 4, July 2005

[6] HOFMANN G.: Bemessung und Betriensfuhrung von Energieversorgungsanlagen elektrischer Bahnen bei Verwendung eines stochastischen Simulationsmodells der elektrischen Bahnbelastung fur den ungestorten Betriebsfall, praca habilitacyjna. VfV, Drezno 1986

[7] KROCZAK M.: Symulacja zelektryfikowanej linii kolejowej o złozonej strukturze zasilajacej, rozprawa doktorska. Warszawa 2008, Politechnika Warszawska

[8] BARTŁOMIEJCZYK M.: Výpočet napájení trolejbusových systémů metodou Monte Carlo, XLII. Sešit Katedry Elektrotechniky, VŠB Ostrava, Ostrava 2010

[9] BARTEOMIEJCZYK M., GIECTKOWSKI Z. ,. Сравнивательный анализ токов нагрузки в троллейбусной тяге, Современный научный вестник, Belgrad 2008

[10] BARTŁOMIEJCZYK M.: Analýza efektivnosti rekuperace trolejbusové dopravy metodou Monte Carlo, XLIII. Sešit Katedry Elektrotechniky, VŠB Ostrava, Ostrava 2010 